\title{
AUDIT MANAJEMEN KUALITAS TEKNOLOGI INFORMASI MENGGUNAKAN COBIT 5 DAN ISO 9001:2015 (STUDI KASUS: KPP PRATAMA PONTIANAK BARAT)
}

\author{
${ }^{[1]}$ Alberth Rico CA, ${ }^{[2]}$ Ilhamsyah, ${ }^{[3]}$ Nurul Mutiah \\ ${ }^{[1][2][3] J u r u s a n ~ S i s t e m ~ I n f o r m a s i ; ~ F a k u l t a s ~ M I P A ~ U n i v e r s i t a s ~ T a n j u n g p u r a ; ~}$ \\ Jalan Prof. Dr. H. Hadari Nawawi, Pontianak \\ Telp / Fax: (0561) 577963 \\ e-mail: ${ }^{[1]}$ alberthrico@student.untan.ac.id, ${ }^{[2]}$ ilhamsyah@sisfo.untan.ac.id, \\ ${ }^{[3]}$ nurul@ sisfo.untan.ac.id
}

\begin{abstract}
Abstrak
Peran Teknologi Informasi (TI) sangatlah penting bagi instansi atau perusahaan dalam menjalankan proses bisnis. Salah satunya adalah KPP Pratama Pontianak Barat, instansi pemerintah yang memberikan pelayanan pajak pada masyarakat dengan memanfaatkan TI. Oleh sebab itu tata kelola TI khususnya manajemen kualitas sangat diperlukan untuk memastikan penerapan dan pemanfaatan TI selaras dengan strategi dan tujuan organisasi. ISO 9001 merupakan standar yang berisi klausul-klausul untuk penerapan sistem manajemen kualitas (QMS). ISO 9001 kemudian diintegrasikan dengan COBIT 5 yang merupakan kerangka kerja dalam tata kelola TI untuk menghasilkan sekumpulan base practice dan work product yang digunakan untuk penilaian level kapabilitas. Penilaian menggunakan COBIT PAM yang merupakan kerangka dasar dalam menilai dan mengukur level kapabillitas. Dari penilaian yang dilakukan, didapatkan hasil berupa klausul konteks organisasi sudah berada di level 2, sedangkan klausul kepemimpinan, klausul perencanaan, klausul pendukung, klausul operasi, klausul evaluasi kinerja dan klausul peningkatan masih berada di level 1. Dari hasil penilaian yang didapat maka akan dibuat rekomendasi perbaikan yang disarankan untuk diimplementasikan agar dapat meningkatkan level kapabilitas ke level yang diharapkan.
\end{abstract}

Kata Kunci: Tata Kelola TI, Sistem Manajemen Kualitas, COBIT 5, COBIT PAM

\section{PENDAHULUAN}

Di era teknologi saat ini peran Teknologi Informasi (TI) bagi sebuah instansi yang memberikan pelayanan kepada masyarakat sangat penting. Namun dalam penerapan TI jika tanpa adanya tata kelola TI maka penerapan atau pengimplementasian TI akan kurang maksimal. Tata kelola TI merupakan upaya organisasi mengelola, mengawasi, memonitoring dan mengendalikan sumber daya agar berdampak terhadap visi, misi dan tujuan organisasi [1]. Salah satu bidang dalam tata kelola TI adalah manajemen kualitas TI.

Manajemen kualitas TI merupakan kegiatan merencanakan, mengorganisir, mengendalikan dan mengevaluasi kualitas TI. Penerapan manajemen kualitas TI yang baik dapat meningkatkan kinerja organisasi karena kualitas yang terjaga dan terkendali mulai dari kualitas software, hardware hingga brainware.

Untuk menerapkan manajemen kualitas, terdapat sebuah konsep yang dinamakan QMS (Quality Management System). Menurut Gaspersz, Quality Management System (Sistem Manajemen Kualitas) adalah prosedur terdokumentasi dan praktik standar dalam sistem manajemen yang digunakan untuk memastikan proses dan produk (atau layanan) sesuai dengan kebutuhan maupun persyaratan pelanggan dan organisasi [2]. Salah satu standar yang umum digunakan dalam manajemen kualitas adalah ISO 9001:2015. ISO 9001:2015 memiliki 10 klausul atau persyaratan yang dapat menjadi pedoman untuk dapat menerapkan konsep sistem manajemen kualitas. Sedangkan untuk penerapan tata kelola TI dapat menggunakan COBIT 5. 
Coding: Jurnal Komputer dan Aplikasi

Volume 8, No. 03 (2020), hal 29-39

ISSN: $2338-493 X$

COBIT 5 adalah serangkaian base practice tata kelola TI yang dapat digunakan oleh pengguna dan manajemen serta auditor untuk menghubungkan gap antara risiko bisnis, kontrol kebutuhan dan masalah-masalah teknis terkait TI [1]. Dengan berpatokan dengan prinsip-prinsip QMS pada ISO 9001:2015 yang sesuai dengan kebutuhan manajemen kualitas TI kemudian menentukan domain mana yang sesuai untuk manajemen kualitas pada COBIT 5 , akan dibuat sebuah pedoman untuk kegiatan audit manajemen kualitas TI di sebuah lembaga atau instansi.

KPP Pratama Pontianak merupakan sebuah lembaga atau instansi yang memberikan pelayanan pajak bagi masyarakat di wilayah Pontianak. Peran TI dalam proses bisnis KPP Pratama Pontianak sangat penting. TI digunakan dalam proses pemberian layanan pajak terhadap pelanggan dan juga digunakan dalam proses kerja KPP Pratama Pontianak secara internal. Sehingga penerapan tata kelola TI khususnya manajemen kualitas TI dapat memberikan keuntungan bagi KPP Pratama Pontianak. Akan tetapi level kapabilitas dari penerapan tata kelola TI khususnya manajemen kualitas TI masih belum diketahui.

Oleh karena itu perlu dilakukan sebuah kegiatan audit manajemen kualitas TI di KPP Pratama Pontianak, untuk mendapat hasil berupa level kapabilitas dari manajemen kualitas TI yang digunakan untuk membuat sebuah rekomendasi perbaikan. Rekomendasi yang dibuat bertujuan untuk meningkatkan kinerja tata kelola TI agar ke depannya dapat mendukung proses bisnis khususnya dalam manajemen kualitas TI bisa menjadi lebih baik lagi.

\section{LANDASAN TEORI}

\subsection{Tata Kelola Teknologi Informasi}

Tata kelola TI adalah serangkaian kegiatan mengontrol perumusan dan pengimplementasian strategi TI serta langkahlangkah untuk dapat menggabungkan aspek bisnis dengan TI yang dilakukan oleh pimpinan, manajemen eksekutif dan manajemen TI [3]. Tata kelola TI bertujuan untuk mengarahkan dan memastikan kesesuaian TI dengan dukungannya dalam mencapai tujuan perusahaan, mengelola sumber daya TI secara bertanggung jawab dan mengelola risiko yang terkait TI [4].

\subsection{Sistem Manajemen Kualitas}

Sistem manajemen kualitas atau biasa disebut QMS (Quality Management System) adalah prosedur terdokumentasi dan praktik standar dalam sistem manajemen yang digunakan untuk memastikan proses dan produk (atau layanan) sesuai dengan kebutuhan maupun persyaratan pelanggan dan organisasi [3]. Sistem manajemen kualitas dibagi menjadi dua, yaitu sistem manajemen kualitas Informal dan formal.

Sistem manajemen kualitas Informal tidak terikat dengan kriteria formal yang ditetapkan oleh institusi lain sehingga manajemen bebas membangun model sistem manajemen kualitas organisasi.. Oleh karena itu, sesuai dengan pemahaman dan keyakinan prinsip manajemen kualitas, manajemen akan menerapkan sistem dan kemudian mengembangkan model sistem manajemen yang sesuai dengan organisasi.

Sedangkan sistem manajemen kualitas formal terikat pada kriteria formal yang ditentukan oleh lembaga konstituen sistem manajemen kualitas. Jika sebuah manajemen ingin menerapkan sistem manajemen kualitas formal dan ingin mendapatkan pengakuan atau mendapatkan penghargaan, manajemen harus dapat membuktikan kelayakannya menerapkan model sistem manajemen kualitas formal.

\subsection{ISO 9001:2015}

ISO 9001:2015 adalah sebuah standar internasional yang menetapkan persyaratan untuk sistem manajemen kualitas. ISO 9001:2015 merupakan versi paling baru. ISO 9001:2015 dapat digunakan oleh organisasi apa pun, besar atau kecil, terlepas dari bidang kegiatannya.

\subsubsection{Prinsip Manajemen Kualitas}

Dalam ISO 9001:2015 terdapat 7 prinsip yang dapat digunakan sebagai dasar untuk kebijakan kualitas dan pengembangan kebijakan tersebut [5]. 7 prinsip tersebut yaitu:
a. Fokus pada pelanggan
b. Kepemimpinan
c. Keterlibatan orang
d. Pendekatan proses
e. Peningkatan
f. Pengambilan keputusan berdasarkan bukti
g. Manajemen hubungan 
Coding: Jurnal Komputer dan Aplikasi

Volume 8, No. 03 (2020), hal 29-39

\subsubsection{Siklus PDCA}

Siklus PDCA merupakan sebuah siklus digunakan untuk memperbaiki kinerja produk, proses atau suatu sistem di masa yang akan datang dengan cara menguji dan mengimplementasikan perubahan-perubahan [6]. Siklus PDCA terdiri dari 4 tahapan, yaitu:

a. Perencanaan (Plan)

Tahap untuk menetapkan spesifikasi atau sebuah standar kualitas yang baik, memastikan pentinganya kesadaran menjaga kualitas produk, serta pengendalian kualitas yang berkelanjutan

b. Melaksanakan rencana (Do)

Tahap untuk mengimplementasikan perencanaan yang sudah dibuat. Organisasi harus mengupayakan agar seluruh rencana dilaksanakan dengan sebaik mungkin agar sasaran dapat tercapai, sehinggan diperlukan sebuah pengendalian

c. Pemeriksaan hasil (Check)

Tahap untuk memeriksa pelaksanaan rencana yang telah dibuat dan memantau perbaikan yang dibuat. Tahap ini juga memeriksa kualitas dari produk yang dihasilkan serta data kegagalan sehingga kemudian dicari penyebab dari kegagalan tersebut

d. Tindakan yang diperlukan (Action)

Pada tahap ini, dilakukan serangkaian tindakan yang perlu dilakukan berdasarkan hasil pada tahap pemeriksaan hasil. Tindakan yang dilakukan dapat berupa pembuatan prosedur baru atau penetapan sasaran baru untuk perbaikan selanjutnya

\subsubsection{Klausul ISO 9001:2015}

ISO 9001:2015 memiliki 7 klausul yang berisi persyaratan tentang manajemen kualitas, yaitu:

a. Klausul 4 Konteks organisasi, terdiri dari 4 subklausul

b. Klausul 5 Kepemimpinan, terdiri dari 3 subklausul

c. Klausul 6 Perencanaan, terdiri dari 3 subklausul

d. Klausul 7 Pendukung, terdiri dari 6 subklausul

e. Klausul 8 Operasi, terdiri dari 6 subklausul

f. Klausul 9 Evaluasi kinerja, terdiri dari 2 subklausul

g. Klausul 10 Peningkatan, terdiri dari 2 subklausul

\subsection{COBIT 5}

ISSN: $2338-493 \mathrm{X}$

COBIT 5 adalah kerangka menyeluruh yang dapat digunakan suatu organisasi untuk mencapai tujuannya dalam tata kelola dan manajemen perusahaan. COBIT 5 membantu organisasi mengoptimalkan TI dengan menjaga keseimbangan antara keuntungan dengan tingkat risiko dan penggunaan sumber daya. COBIT 5 bersifat umum sehingga dapat diterapkan di berbagai jenis perusahaan seperti perusahaan komersial, non-profit atau pada sektor pemerintahan maupun publik [7].

\subsubsection{Prinsip COBIT 5}

Terdapat 5 prinsip utama dalam COBIT 5 yang dapat digunakan dalam tata kelola dan manajemen TI perusahaan [7], yaitu:

a. Memenuhi kebutuhan stakeholder

b. Melingkupi tata kelola dan proses kerja endto-end enterprise

c. Mengaplikasikan sebuah kerangka kerja yang terintegrasi

d. Pendekatan keseluruhan untuk kemampuan tata kelola dan manajemen atau pengetahuan

e. Pemisahan antara tata kelola dengan manajemen atau pengetahuan

\subsubsection{Domain COBIT 5}

COBIT 5 membagi proses tata kelola dan manajemen TI perusahaan ke dalam dua domain proses utama yaitu governance dan management. Governance memiliki 1 domain yaitu EDM (Evaluate, Direct, and Monitor) yang terdapat 5 proses didalamnya. Management memiliki 4 domain yaitu Align, Plan and Organise (APO) dengan 13 proses, Build, Acquire and Implement (BAI) dengan 10 proses, Deliver, Service and Support (DSS) dengan 6 proses dan Monitor, Evaluate and Assess (MEA) dengan 3 proses.

\subsection{COBIT PAM (Process Assessment Model)}

Process Assessment Model (PAM) merupakan serangkaian dokumen penilaian COBIT yang menjadi pedoman untuk mengukur kinerja kapabilitas proses TI dalam sebuah organisasi. Kapabilitas proses mengidentifikasikan kapabilitas level suatu proses tertentu dalam organisasi [8]. Kapabilitas proses mengidentifikasikan kapabilitas level suatu proses tertentu dalam organisasi. Kapabilitas proses memiliki 6 level 
Coding: Jurnal Komputer dan Aplikasi

Volume 8, No. 03 (2020), hal 29-39

yang digunakan untuk mengukur kapabilitas tata kelola TI. 6 level tersebut, yaitu:

a. Level 0 - Incomplete Process

Pada level ini tidak dijalankan atau gagal untuk mencapai tujuan proses

b. Level 1 - Performed Process

Proses telah diimplementasikan dan dapat mencapai tujuan proses

c. Level 2 - Managed Process

Proses yang diimplementasikan dikelola dan hasilnya di tetapkan serta dikontrol

d. Level 3 - Established Process

Proses yang diimplementasikan dikelola menggunakan proses terdefinisi dan dapat mencapai hasil prosesnya

e. Level 4 - Predictable Process

Proses berjalan dengan batasan terdefinisi untuk mencapai hasil prosesnya

f. Level 5 - Optimizing Proccess

Proses yang diprediksi telah dikembangkan secara berkelanjutan untuk mencapai tujuan bisnis saat ini

Dalam penilaian terdapat 2 indikator yaitu kapabilitas proses yang menggunakan Generic Practice (GP) dan Generic Work Product (GWP) untuk level 1 sampai 5 dan juga kinerja proses menggunakan Base practice (BP) dan Work Product (WP) untuk level 1. Berdasarkan standar ISO/IEC 15504 penilaian dilakukan dengan melihat atribut dari indikator yang telah tercapai [9]. Skala penilaian tersebut adalah sebagai berikut:

a. N-Not achieved

Atribut tidak tercapai dengan persentase penilaian diantara $0-15 \%$

b. P - Partially achieved

Sebagian atribut tercapai dengan persentase penilaian diantara $15-50 \%$

c. L - Largely achieved

Sebagian besar atribut tercapai dengan persentase penilaian antara $50-85 \%$

d. F-Fully achieved

Atribut sepenuhnya tercapai dengan persentase penilaian diantara $85-100 \%$

Untuk melewati sebuah proses level kapabilitas, sebuah proses harus mencapai antara L - Largely atau F - Fully. Jika ingin menuju level selanjutnya, semua kekurangan yang terdapat pada di level L - Largely harus diperbaiki dan dikembang ke F - Fully.

\section{METODE PENELITIAN}

ISSN: $2338-493 \mathrm{X}$

Metodologi penelitian yang digunakan dalam melakukan penelitian ini adalah design science. secara umum design science dibagi menjad 3 bagian yaitu Environment, IS Research dan Knowledge base. Metodologi yang digunakan dapat dilihat pada gambar 1 .

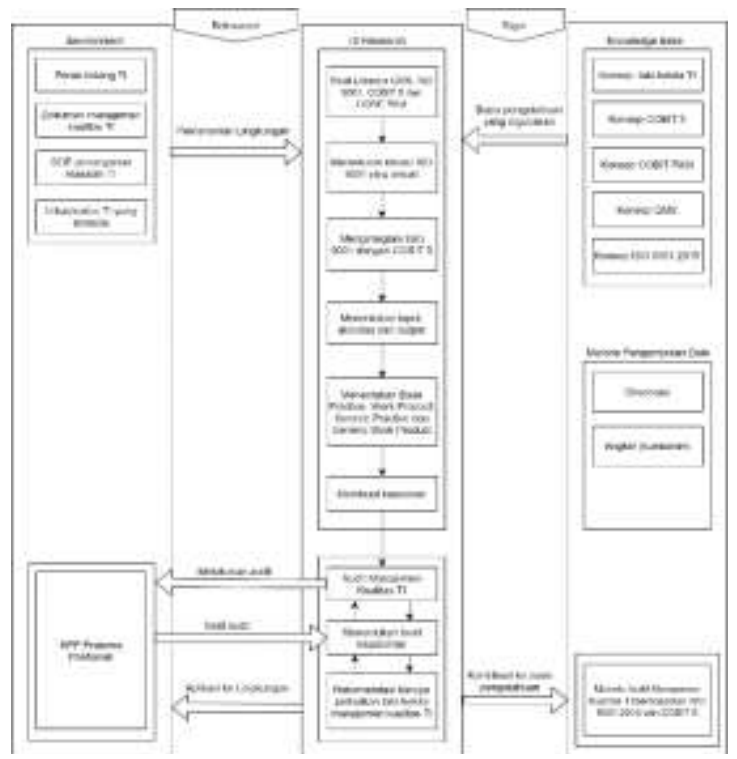

Gambar 1. Kerangka kerja penelitian

\subsection{Environment}

Pada bagian ini berisikan lingkungan dari tempat penelitian yang dapat menunjang atau diperlukan untuk terlibat dalam penelitian. Dalam penelitian ini yang perlukan adalah peran bidang TI di KPP Pratama Pontianak Barat, dokumen yang terkait manajemen kualitas, SOP penenganan masalah TI serta infrastruktur yang tersedia.

\subsection{IS Research}

Bagian ini berikan tahapan - tahapan penelitian yang akan dilakukan, yaitu;

a. Melakukan studi literatur berupa mencari dasar teori yang akan digunakan dalam penelitian ini seperti dokumen ISO 9001:2015 dan COBIT 5, teori tentang tata kelola TI serta COBIT 5 PAM

b. Melakukan penentuan untuk klausul mana yang sesuai dengan penelitian ini berdasarkan keadaan di tempat studi kasus

c. Menentukan dan menyesuaikan domain pada COBIT 5 dengan persyaratan yang ada pada klausul ISO 9001:2015

d. Menentukan input, aktivitas dan output dari COBIT 5 yang telah diintegrasikan dengan klausul ISO 9001:2015

e. Menentukan base practice (BP), work product (WP), generic practice (GP) dan 
Coding: Jurnal Komputer dan Aplikasi

Volume 8, No. 03 (2020), hal 29-39

generic work product (GWP) berdasarkan pada input, aktivitas dan output yang telah ditentukan pada tahap sebelumnya

f. Membuat kuesioner tata kelola TI berdasarkan pada BP, WP, GP serta GWP yang telah ditentukan ditahap sebelumnya

g. Melakukan kegiatan audit di KPP Pratama Pontianak Barat. Responden mengisi kuesioner yang telah dibuat

h. Melakukan perhitungan level kapabilitas berdasarkan hasil audit yang telah dilakukan

i. Membuat rekomendasi untuk perbaikan tata kelola manajemen kualitas TI di KPP Pratama Pontianak Barat berdasarkan level kapabilitas yang telah dicapai

Tahapan penelitian harus sesuai (relevance) terhadap lingkungan penelitian. Tahapan penelitan dibuat berdasarkan keadaan yang nyata di tempat penelitian serta penelitian yang dilakukan harus menggunakan konsep serta metode yang kuat (rigor) sebagai dasar ilmu yang berguna untuk menunjang penelitian.

\subsection{Knowledge Base}

Bagian ini berisikan konsep - konsep serta metode yang digunakan untuk menunjang penelitian. Konsep dan metode yang digunakan yaitu:

a. Konsep tata kelola teknologi informasi

b. Konsep Quality Management System (QMS)

c. Konsep ISO 9001:2015

d. Konsep COBIT 5

e. Metode pengumpulan data

\section{HASIL DAN PEMBAHASAN}

\subsection{Metode Pemetaan ISO 9001:2015 dan COBIT 5}

Proses tata kelola TI dan proses Quality Management System (QMS) dapat diterapkan secara bersama berdasarkan kesamaan aspek untuk dapat meningkatkan kualitas proses TI yang terintegrasi dengan QMS. Pemetaan dilakukan dengan cara membandingkan area domain pada COBIT 5 dengan persyaratan atau klausul dari ISO 9001:2015 yang saling melengkapi dan dapat dicocokkan [10]. Sebagai contoh, Klausul 4.4 pada ISO 9001:2015 yang berisi tentang sistem manajemen kualitas dan prosesnya sesuai dengan domain pada COBIT 5 yaitu domain APO 11 mengelola kualitas. Klausul 4.4 mensyaratkan untuk menetapkan, menerapkan, memelihara dan terus meningkatkan sistem manajemen kualitas,
ISSN: 2338-493X

termasuk proses yang diperlukan dan interaksinya. Domain APO 11 berfokus untuk menentukan dan mengkomunikasikan kebutuhan/persyaratan kualitas di semua proses, prosedur termasuk kontrol, pemantauan dan penerapan praktik serta standar untuk peningkatan yang berkelanjutan dan usaha yang efisien.

Contoh lainnya yaitu, klausul 5.3 sesuai dengan domain APO 01.02 yang sama-sama berfokus pada peran dan tanggung jawab dalam organisasi atau perusahaan. Klausul 6.1 tentang tindakan untuk mengatasi risiko dan peluang sesuai dengan domain APO 12 yang berfokus untuk mengelola risiko. Untuk pemetaan antara ISO 9001:2015 dan COBIT 5 secara umum dapat dilihat di tabel 1 .

Tabel 1. Relasi COBIT 5 dengan ISO 9001:2015

\begin{tabular}{|c|c|c|c|c|c|c|c|c|}
\hline \multirow{2}{*}{\multicolumn{2}{|c|}{ Domain COBIT 5}} & \multicolumn{7}{|c|}{ Klausul ISO 9001:2015 } \\
\hline & & 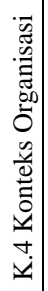 & 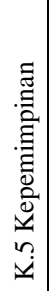 & 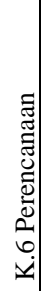 & 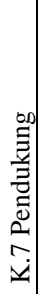 & 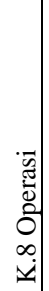 & 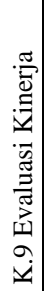 & 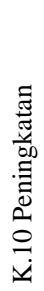 \\
\hline \multirow{12}{*}{ 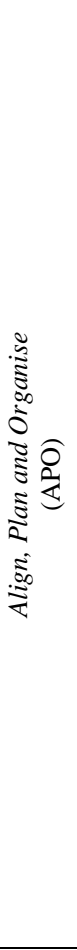 } & $\begin{array}{c}\text { 01 Mengelola } \\
\text { kerangka kerja } \\
\text { manajemen TI }\end{array}$ & $\checkmark$ & $\checkmark$ & & $\checkmark$ & $\checkmark$ & & \\
\hline & $\begin{array}{l}02 \text { Mengelola } \\
\text { strategi }\end{array}$ & $\checkmark$ & & & $\checkmark$ & & & \\
\hline & $\begin{array}{c}\text { 03 Mengelola } \\
\text { arsitektur } \\
\text { perusahaan }\end{array}$ & & & & & & & \\
\hline & $\begin{array}{l}04 \text { Mengelola } \\
\text { inovasi }\end{array}$ & & & & & & & \\
\hline & $\begin{array}{c}05 \text { Mengelola } \\
\text { portofolio }\end{array}$ & & & & & & & \\
\hline & $\begin{array}{c}\text { 06 Mengelola } \\
\text { anggaran dan } \\
\text { biaya }\end{array}$ & & & & & & & \\
\hline & $\begin{array}{c}\text { 07 Mengelola } \\
\text { sumber daya } \\
\text { manusia }\end{array}$ & & & & $\checkmark$ & & & \\
\hline & $\begin{array}{l}\text { 08 Mengelola } \\
\text { hubungan }\end{array}$ & & & $\checkmark$ & & & & \\
\hline & $\begin{array}{c}\text { 09 Mengelola } \\
\text { perjanjian } \\
\text { layanan }\end{array}$ & $\checkmark$ & & & & $\checkmark$ & & \\
\hline & $\begin{array}{c}10 \text { Mengelola } \\
\text { suppliers }\end{array}$ & & & & & $\checkmark$ & & \\
\hline & $\begin{array}{l}11 \text { Mengelola } \\
\text { kualitas }\end{array}$ & $\checkmark$ & $\checkmark$ & $\checkmark$ & $\checkmark$ & $\checkmark$ & $\checkmark$ & $\checkmark$ \\
\hline & $\begin{array}{l}12 \text { Mengelola } \\
\text { risiko }\end{array}$ & $\checkmark$ & & $\checkmark$ & & & & \\
\hline \multicolumn{9}{|c|}{$\begin{array}{c}\text { Tabel 1. Relasi COBIT } 5 \text { dengan ISO } \\
\text { 9001:2015 (Lanjutan) }\end{array}$} \\
\hline \multicolumn{2}{|c|}{ Domain COBIT 5} & \multicolumn{7}{|c|}{ Klausul ISO 9001:2015 } \\
\hline
\end{tabular}


Coding: Jurnal Komputer dan Aplikasi

Volume 8, No. 03 (2020), hal 29-39

\begin{tabular}{|c|c|c|c|c|c|c|c|c|}
\hline & & 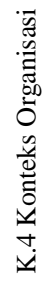 & 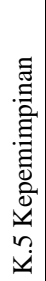 & 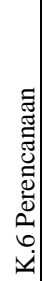 & 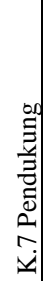 & 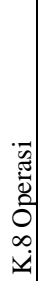 & 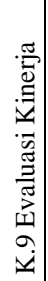 & 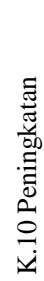 \\
\hline & $\begin{array}{l}13 \text { Mengelola } \\
\text { keamanan }\end{array}$ & & & & & & & \\
\hline \multirow{10}{*}{ 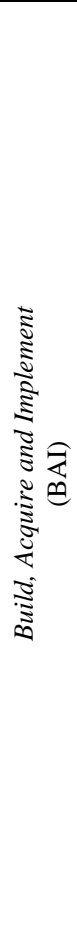 } & $\begin{array}{l}\text { 01 Mengelola } \\
\text { program dan } \\
\text { proyek }\end{array}$ & & & & & & & \\
\hline & $\begin{array}{l}02 \text { Mengelola } \\
\text { definisi } \\
\text { persyaratan }\end{array}$ & & & & & & & \\
\hline & $\begin{array}{c}\text { 03 Mengelola } \\
\text { identifikasi dan } \\
\text { pembuatan } \\
\text { solusi }\end{array}$ & & & & & & & \\
\hline & $\begin{array}{c}\text { 04 Mengelola } \\
\text { ketersediaan } \\
\text { dan kapasitas }\end{array}$ & & & & & $\checkmark$ & & \\
\hline & $\begin{array}{c}05 \text { Mengelola } \\
\text { pemberdayaan } \\
\text { perubahan } \\
\text { organisasi } \\
\end{array}$ & & & & & & & \\
\hline & $\begin{array}{l}06 \text { Mengelola } \\
\text { perubahan }\end{array}$ & $\checkmark$ & & $\checkmark$ & & $\checkmark$ & & \\
\hline & $\begin{array}{c}07 \text { Mengelola } \\
\text { penerimaan dan } \\
\text { transisi } \\
\text { perubahan }\end{array}$ & & & & & & & \\
\hline & $\begin{array}{l}\text { 08 Mengelola } \\
\text { pengetahuan }\end{array}$ & & & & $\checkmark$ & & & \\
\hline & $\begin{array}{l}09 \text { Mengelola } \\
\text { aset }\end{array}$ & & & & & & & \\
\hline & $\begin{array}{l}10 \text { Mengelola } \\
\text { konfigurasi }\end{array}$ & & & & & & & \\
\hline \multirow{6}{*}{ 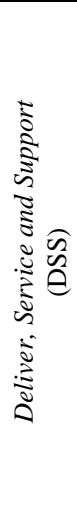 } & $\begin{array}{l}01 \text { Mengelola } \\
\text { operasi }\end{array}$ & & & & $\checkmark$ & $\checkmark$ & & \\
\hline & $\begin{array}{l}02 \text { Mengelola } \\
\text { permintaan dan } \\
\text { insiden layanan }\end{array}$ & & & & & $\checkmark$ & & \\
\hline & $\begin{array}{c}03 \text { Mengelola } \\
\text { masalah }\end{array}$ & & & & & $\checkmark$ & $\checkmark$ & $\checkmark$ \\
\hline & $\begin{array}{l}04 \text { Mengelola } \\
\text { kontinuitas atau } \\
\text { kesinambungan }\end{array}$ & & & & & & & \\
\hline & $\begin{array}{c}05 \text { Mengelola } \\
\text { layanan } \\
\text { keamanan } \\
\end{array}$ & & & & & & & \\
\hline & $\begin{array}{l}06 \text { Mengelola } \\
\text { kontrol proses } \\
\text { bisnis }\end{array}$ & & & & & & & \\
\hline \multirow{3}{*}{ 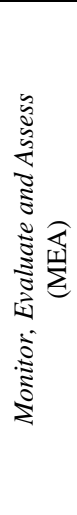 } & $\begin{array}{c}\text { 01 Memantau, } \\
\text { mengevaluasi } \\
\text { dan menilai } \\
\text { kinerja dan } \\
\text { kesesuaian }\end{array}$ & & & & $\checkmark$ & $\checkmark$ & & \\
\hline & $\begin{array}{c}\text { 02 Memantau, } \\
\text { mengevaluasi } \\
\text { dan menilai } \\
\text { sistem } \\
\text { pengendalian } \\
\text { internal } \\
\end{array}$ & & & & & & & \\
\hline & $\begin{array}{c}\text { 03 Memantau, } \\
\text { mengevaluasi } \\
\text { dan menilai } \\
\text { kepatuhan } \\
\text { terhadap }\end{array}$ & & & & & & & \\
\hline
\end{tabular}

ISSN: $2338-493 \mathrm{X}$

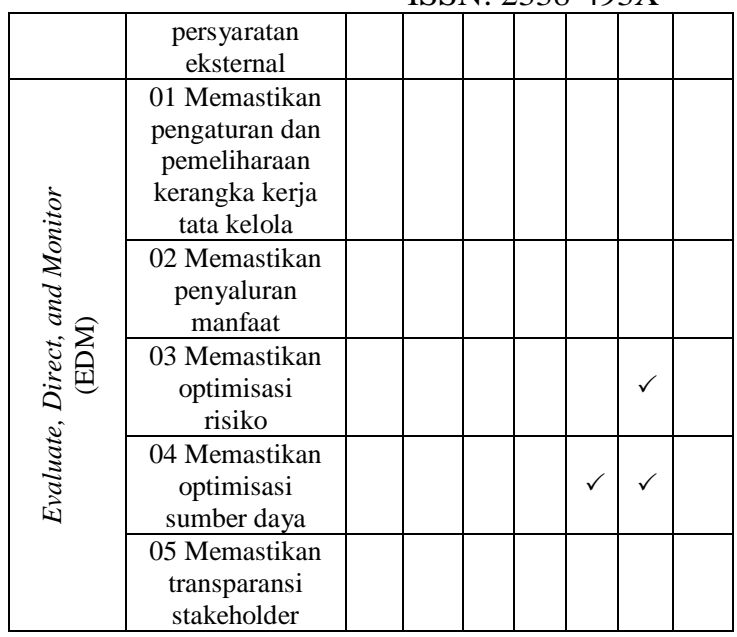

ISO 9001:2015 diintegrasikan dengan COBIT 5 berdasarkan kesesuaian antara klausul-klausul ISO 9001:2015 dengan input, output serta aktivitas dari domain COBIT 5. Sehingga input, output dan aktivitas yang digunakan sudah berdasarkan prinsip manajemen kualitas yang terdapat dalam klausul ISO 9001:2015.

\subsection{Base Practice (BP), Work Product (WP), Generic Practice (GP) dan Generic Work Product (GWP)}

Base Practice dan Work Product digunakan untuk menilai level kapabilitas mulai dari level 0 hingga level 1. Base Practice (BP) merupakan aktivitas dari COBIT 5 yang dilakukan oleh organisasi. Sedangkan Work Product (WP) merupakan input dan output dari COBIT 5 yang dihasilkan oleh organisasi. Untuk mengukur tingkat kapabilitas pada pada pada level 2 hingga 5 dapat menggunakan Generic Practice (GP) dan Generic Work Products (GWP).

\section{PENILAiAn TATA Kelola \\ 5.1 Pengukuran Tingkat Kapabilitas}

Setelah dilakukan proses audit dengan menggunakan kuesioner yang telah diberikan kepada Kepala Seksi Pengolahan Data dan Informasi, Kepala Seksi Pelayan,dan Kepala Subbagian Umum dan Kepatuhan Internal. maka dilakukan perhitungan atau pengukuran tingkat kapabilitas di setiap proses dimulai dari level 0 . Pengukuran untuk setiap proses pada level 0 dapat dilihat pada tabel 2 .

Tabel 2. Pengukuran kapabilitas level 0

\begin{tabular}{|c|c|c|c|c|c|c|c|}
\hline \multicolumn{7}{|l|}{ Level 0 } \\
\cline { 1 - 3 } No & \multirow{2}{*}{ Proses } & \multirow{2}{*}{$\begin{array}{c}\text { Jumlah } \\
\text { Pertanyaan }\end{array}$} & \multicolumn{2}{|c|}{$\begin{array}{c}\text { Jumlah } \\
\text { Jawaban }\end{array}$} & Hasil & $\begin{array}{c}\text { Skala } \\
\text { Pengukuran }\end{array}$ \\
\cline { 5 - 6 } & & \multicolumn{2}{|l|}{ Ya } & Tidak & & \\
\hline 1. & 4 & BP & 12 & 12 & 0 & $94 \%$ & \\
\hline
\end{tabular}


Coding: Jurnal Komputer dan Aplikasi

Volume 8, No. 03 (2020), hal 29-39

\begin{tabular}{|c|c|c|c|c|c|c|c|}
\hline & & WP & 20 & 18 & 2 & & $\begin{array}{c}\mathrm{F}(85 \%- \\
100 \%)\end{array}$ \\
\hline \multirow{2}{*}{2.} & \multirow{2}{*}{$\begin{array}{l}\text { Klausul } \\
5\end{array}$} & BP & 13 & 11 & 2 & \multirow{2}{*}{$83 \%$} & \multirow{2}{*}{$\begin{array}{c}\mathrm{L}(50 \% \\
85 \%)\end{array}$} \\
\hline & & WP & 16 & 13 & 3 & & \\
\hline \multirow{2}{*}{3.} & \multirow{2}{*}{$\begin{array}{l}\text { Klausul } \\
6\end{array}$} & BP & 16 & 14 & 2 & \multirow{2}{*}{$83 \%$} & \multirow{2}{*}{$\begin{array}{c}\mathrm{L}(50 \%- \\
85 \%)\end{array}$} \\
\hline & & WP & 14 & 11 & 3 & & \\
\hline \multirow{2}{*}{4.} & \multirow{2}{*}{$\begin{array}{l}\text { Klausul } \\
7\end{array}$} & BP & 16 & 13 & 3 & \multirow{2}{*}{$77 \%$} & \multirow{2}{*}{$\begin{array}{c}\mathrm{L}(50 \%- \\
85 \%)\end{array}$} \\
\hline & & WP & 28 & 21 & 7 & & \\
\hline \multirow{2}{*}{5.} & \multirow{2}{*}{$\begin{array}{l}\text { Klausul } \\
8\end{array}$} & BP & 16 & 13 & 3 & \multirow{2}{*}{$82 \%$} & \multirow{2}{*}{$\begin{array}{c}\mathrm{L}(50 \%- \\
85 \%)\end{array}$} \\
\hline & & WP & 28 & 23 & 5 & & \\
\hline \multirow{2}{*}{6.} & \multirow{2}{*}{$\begin{array}{l}\text { Klausul } \\
9\end{array}$} & BP & 8 & 6 & 2 & \multirow{2}{*}{$82 \%$} & \multirow{2}{*}{$\begin{array}{c}\mathrm{L}(50 \%- \\
85 \%)\end{array}$} \\
\hline & & WP & 11 & 10 & 1 & & \\
\hline \multirow{2}{*}{7.} & \multirow{2}{*}{$\begin{array}{l}\text { Klausul } \\
10\end{array}$} & BP & 9 & 8 & 1 & \multirow{2}{*}{$84 \%$} & \multirow{2}{*}{$\begin{array}{r}\mathrm{L}(50 \% \\
85 \%)\end{array}$} \\
\hline & & WP & 10 & 8 & 2 & & \\
\hline
\end{tabular}

Dari hasil pengukuran level 0, dapat lihat bahwa semua klausul dapat masuk ke level 1 karena untuk dapat ke level 1 harus memiliki nilai skala pengukuran L (50\%-85\%) atau $\mathrm{F}$ (85\%-100\%). Klausul 4 bernilai F (85\%-100\%) dan klausul 5 sampai klausul 10 bernilai L (50\%-85\%). Pengukuran untuk setiap proses pada level 1 dapat dilihat pada tabel 3 .

Tabel 3. Pengukuran kapabilitas level 1

\begin{tabular}{|c|c|c|c|c|c|c|c|}
\hline \multicolumn{8}{|c|}{ Level 1 (PA1.1) } \\
\hline \multirow[t]{2}{*}{ No } & \multirow[t]{2}{*}{ Proses } & \multicolumn{2}{|c|}{$\begin{array}{c}\text { Jumlah } \\
\text { Pertanyaan }\end{array}$} & \multicolumn{2}{|c|}{$\begin{array}{c}\text { Jumlah } \\
\text { Jawaban }\end{array}$} & \multirow[t]{2}{*}{ Hasil } & \multirow[t]{2}{*}{$\begin{array}{c}\text { Skala } \\
\text { Pengukuran }\end{array}$} \\
\hline & & & & Ya & Tidak & & \\
\hline \multirow{2}{*}{1.} & \multirow{2}{*}{$\begin{array}{l}\text { Klausul } \\
4\end{array}$} & BP & 12 & 12 & 0 & \multirow{2}{*}{$94 \%$} & \multirow{2}{*}{$\begin{array}{l}F(85 \%- \\
100 \%)\end{array}$} \\
\hline & & WP & 20 & 18 & 2 & & \\
\hline \multirow{2}{*}{2.} & \multirow{2}{*}{$\begin{array}{l}\text { Klausul } \\
5\end{array}$} & $\mathrm{BP}$ & 13 & 11 & 2 & \multirow{2}{*}{$83 \%$} & \multirow{2}{*}{$\begin{array}{l}\text { L }(50 \%- \\
85 \%)\end{array}$} \\
\hline & & WP & 16 & 13 & 3 & & \\
\hline \multirow{2}{*}{3.} & \multirow{2}{*}{$\begin{array}{l}\text { Klausul } \\
6\end{array}$} & $\mathrm{BP}$ & 16 & 14 & 2 & \multirow{2}{*}{$83 \%$} & \multirow{2}{*}{$\begin{array}{l}\text { L }(50 \%- \\
85 \%)\end{array}$} \\
\hline & & WP & 14 & 11 & 3 & & \\
\hline \multirow{2}{*}{4.} & \multirow{2}{*}{$\begin{array}{l}\text { Klausul } \\
7\end{array}$} & $\mathrm{BP}$ & 16 & 13 & 3 & \multirow{2}{*}{$77 \%$} & \multirow{2}{*}{$\begin{array}{l}\mathrm{L}(50 \%- \\
85 \%)\end{array}$} \\
\hline & & WP & 28 & 21 & 7 & & \\
\hline
\end{tabular}

ISSN: $2338-493 \mathrm{X}$

\begin{tabular}{|c|c|c|c|c|c|c|c|}
\hline \multirow[t]{2}{*}{5.} & \multirow[t]{2}{*}{ Klausul 8} & BP & 16 & 13 & 3 & \multirow{2}{*}{$82 \%$} & \multirow{2}{*}{$\begin{array}{c}\text { L }(50 \%- \\
85 \%)\end{array}$} \\
\hline & & WP & 28 & 23 & 5 & & \\
\hline \multirow{2}{*}{6.} & \multirow{2}{*}{ Klausul 9} & BP & 8 & 6 & 2 & \multirow{2}{*}{$82 \%$} & \multirow{2}{*}{$\begin{array}{c}\mathrm{L}(50 \%- \\
85 \%)\end{array}$} \\
\hline & & WP & 11 & 10 & 1 & & \\
\hline \multirow{2}{*}{7.} & \multirow{2}{*}{ Klausul 10} & BP & 9 & 8 & 1 & \multirow{2}{*}{$84 \%$} & \multirow{2}{*}{$\begin{array}{c}\mathrm{L}(50 \%- \\
85 \%)\end{array}$} \\
\hline & & WP & 10 & 8 & 2 & & \\
\hline
\end{tabular}

Dari hasil pengukuran level 1, dapat lihat bahwa hanya klausul 4 yang memiliki nilai skala F (85\%-100\%) sehingga penilaian dapat dilakukan kembali dengan menggunakan PA2.1 dan PA2.2 (GP dan GWP) untuk memastikan base practice dan work product dikelola dengan baik dan benar. Pengukuran untuk setiap proses pada level 2 dapat dilihat pada tabel 4 .

Tabel 4. Pengukuran kapabilitas level 2

\begin{tabular}{|c|c|c|c|c|c|c|}
\hline \multicolumn{7}{|c|}{ Level 2 (PA2.1 dan PA2.2) } \\
\hline \multirow[t]{2}{*}{ Proses } & \multirow{2}{*}{\multicolumn{2}{|c|}{ Pertanyaan }} & \multicolumn{2}{|c|}{$\begin{array}{c}\text { Jumlah } \\
\text { Jawaban }\end{array}$} & \multirow{3}{*}{$\begin{array}{r}\text { Hasil } \\
67 \%\end{array}$} & \multirow{3}{*}{$\begin{array}{c}\begin{array}{c}\text { Skala } \\
\text { Pengukuran }\end{array} \\
\text { L }(50 \%-85 \%)\end{array}$} \\
\hline & & & Ya & Tidak & & \\
\hline \multirow{2}{*}{$\begin{array}{l}\text { Klausul } \\
4\end{array}$} & $\begin{array}{c}\text { PA2. } \\
1\end{array}$ & 6 & 4 & 2 & & \\
\hline & $\begin{array}{c}\text { PA2. } \\
2\end{array}$ & 4 & 4 & 0 & $100 \%$ & $\begin{array}{l}\mathrm{F}(85 \%- \\
100 \%)\end{array}$ \\
\hline
\end{tabular}

Dari hasil pengukuran level 2 pada tabel 5.3, dapat dilihat bahwa klausul 4 konteks organisasi berhasil mencapai level 2 karena PA2.1 memiliki nilai skala pengukuran L (50\%$85 \%$ ) dan PA2.2 memiliki nilai skala pengukuran F (85\%-100\%). Namun klausul 4 konteks organisasi tidak berhasil masuk ke pengukuran level 3 karena untuk dapat masuk ke pengukuran level 3, PA2.1 dan PA2.2 harus memiliki nilai skala pengukuran $\mathrm{F}(85 \%$ $100 \%$ ).

\subsection{Analisis GAP}

Berdasarkan pengukuran didapat level kapabilitas untuk saat ini dari setiap proses. Dari hasil tersebut dapat dilakukan analisis gap untuk mengetahui kesenjangan antara tingkat kapabilitas saat ini dan tingkat kapabilitas yang diharapkan. Adapun hasil analisis GAP dapat dilihat pada tabel 5 .

Tabel 5. Analisis GAP

\begin{tabular}{|c|l|c|c|c|}
\hline No & \multicolumn{1}{|c|}{ Proses } & $\begin{array}{c}\text { Level } \\
\text { saat } \\
\text { ini }\end{array}$ & $\begin{array}{c}\text { Level yang } \\
\text { diharapkan }\end{array}$ & GAP \\
\hline 1. & $\begin{array}{l}\text { Konteks } \\
\text { organisasi }\end{array}$ & 2 & 4 & -2 \\
\hline 2. & Kepemimpinan & 1 & 3 & -2 \\
\hline
\end{tabular}

Tabel 5. Analisis GAP (Lanjutan) 
Coding: Jurnal Komputer dan Aplikasi

Volume 8, No. 03 (2020), hal 29-39

\begin{tabular}{|l|l|c|c|c|}
\hline No & \multicolumn{1}{|c|}{ Proses } & $\begin{array}{c}\text { Level } \\
\text { saat } \\
\text { ini }\end{array}$ & $\begin{array}{c}\text { Level yang } \\
\text { diharapkan }\end{array}$ & GAP \\
\hline 3. & Perencanaan & 1 & 3 & -2 \\
\hline 4. & Pendukung & 1 & 3 & -2 \\
\hline 5. & Operasi & 1 & 2 & -1 \\
\hline 6. & $\begin{array}{l}\text { Evaluasi } \\
\text { Kinerja }\end{array}$ & 1 & 3 & -2 \\
\hline 7. & Peningkatan & 1 & 3 & -2 \\
\hline
\end{tabular}

\subsection{Analisis Kekuatan (Strength) dan Kelemahan (Weakness)}

Analisis kekuatan dan kelemahan untuk setiap proses manajemen kualitas TI pada KPP Pratama Pontianak Barat dapat dilihat pada tabel 6.

Tabel 6. Analisis kekuatan dan kelemahan

\begin{tabular}{|c|c|c|c|c|}
\hline No & Proses & & Kekuatan & Kelemahan \\
\hline 1. & $\begin{array}{l}\text { Konteks } \\
\text { Organisasi }\end{array}$ & 1) & $\begin{array}{l}\text { Memiliki } \\
\text { katalog/portof } \\
\text { olio layanan. } \\
\text { Memiliki } \\
\text { dokumen } \\
\text { perencanaan } \\
\text { untuk } \\
\text { manajemen } \\
\text { kualitas TI. } \\
\text { Memiliki } \\
\text { dokumen hasil } \\
\text { peninjauan } \\
\text { kualitas dan } \\
\text { kegiatan audit. } \\
\text { Memiliki } \\
\text { dokumen } \\
\text { tentang } \\
\text { perbaikan } \\
\text { portofolio } \\
\text { program, } \\
\text { layanan dan } \\
\text { asset. }\end{array}$ & 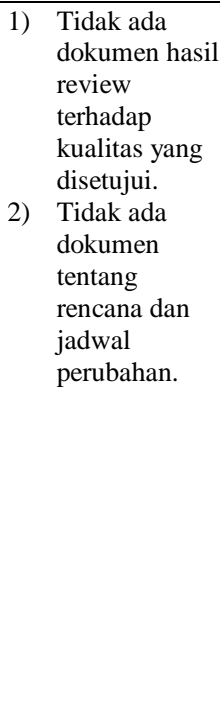 \\
\hline 2. & $\begin{array}{l}\text { Kepemim- } \\
\text { pinan }\end{array}$ & 1) & $\begin{array}{l}\text { Secara berkala } \\
\text { melakukan } \\
\text { penilaian } \\
\text { kinerja } \\
\text { terhadap } \\
\text { kerangka kerja } \\
\text { yang } \\
\text { membantu dan } \\
\text { mengambil } \\
\text { tindakan yang } \\
\text { sesuai. } \\
\text { Memiliki } \\
\text { dokumen hasil } \\
\text { efektivitas } \\
\text { sistem } \\
\text { manajemen } \\
\text { kualitas. } \\
\text { Mengintegrasika } \\
\text { n praktik } \\
\text { manajemen } \\
\text { kualitas dengan } \\
\text { proses dan } \\
\text { praktik } \\
\text { pengembangan } \\
\text { solusi. } \\
\text { Memiliki } \\
\text { dokumen yang }\end{array}$ & $\begin{array}{l}\text { 1)Tidak ada } \\
\text { dokumen hasil } \\
\text { pemantauan } \\
\text { kualitas solusi } \\
\text { dan layanan. } \\
\text { 2)Tidak } \\
\text { memonitor dan } \\
\text { meninjau sistem } \\
\text { manajemen } \\
\text { kualitas (QMS) } \\
\text { terhadap kriteria } \\
\text { penerimaan } \\
\text { yang disepakati } \\
\text { yang berupa } \\
\text { umpan balik } \\
\text { dari pelanggan, } \\
\text { pengguna, dan } \\
\text { manajemen. }\end{array}$ \\
\hline
\end{tabular}

ISSN: 2338-493X

\begin{tabular}{|c|c|c|c|c|}
\hline & & 5) & $\begin{array}{l}\text { mendefinisika } \\
\text { n peran dan } \\
\text { tanggung } \\
\text { jawab terkait } \\
\text { TI. } \\
\text { Ada membuat } \\
\text { dan } \\
\text { menegakkan } \\
\text { kebijakan TI } \\
\text { untuk semua } \\
\text { staf yang } \\
\text { relevan. }\end{array}$ & $\begin{array}{l}\text { pengkomunikasi } \\
\text { an peningkatan } \\
\text { berkelanjutan } \\
\text { dan praktik } \\
\text { terbaiknya. }\end{array}$ \\
\hline 3. & $\begin{array}{l}\text { Perenca- } \\
\text { naan }\end{array}$ & 1) & $\begin{array}{l}\text { Mengidentifik } \\
\text { asi dan } \\
\text { berkomunikasi } \\
\text { dengan } \\
\text { stakeholder } \\
\text { tentang } \\
\text { peluang, risiko } \\
\text { dan kendala. } \\
\text { Memiliki } \\
\text { dokumen } \\
\text { tentang } \\
\text { prosedur } \\
\text { tindakan } \\
\text { perbaikan } \\
\text { untuk } \\
\text { mengatasi } \\
\text { penyimpangan } \\
\text { manajemen } \\
\text { risiko. } \\
\text { Memiliki } \\
\text { dokumen } \\
\text { perencana } \\
\text { untuk } \\
\text { merespon } \\
\text { insiden yang } \\
\text { mungkin } \\
\text { terjadi terkait } \\
\text { risiko. } \\
\text { Melakukan } \\
\text { perancanaan } \\
\text { dan } \\
\text { mengevaluasi } \\
\text { permintaan } \\
\text { perubahan } \\
\text { secara } \\
\text { terstruktur. } \\
\text { Memiliki } \\
\text { laporan } \\
\text { tentang } \\
\text { permintaan } \\
\text { perubahan } \\
\text { yang disetujui. }\end{array}$ & $\begin{array}{l}\text { 1)Tidak mendata } \\
\text { informasi } \\
\text { tentang status } \\
\text { rencana } \\
\text { tindakan risiko } \\
\text { dan dimasukkan } \\
\text { dalam profil } \\
\text { risiko TI } \\
\text { instansi. } \\
\text { 2)Tidak ada } \\
\text { dokumen } \\
\text { tentang profil } \\
\text { risiko yang } \\
\text { teragregasi } \\
\text { beserta status } \\
\text { tindakan } \\
\text { manajemen } \\
\text { risiko. } \\
\text { 3)Tidak ada } \\
\text { dokumen } \\
\text { persyaratan atau } \\
\text { kebutuhan } \\
\text { pelanggan untuk } \\
\text { manajemen } \\
\text { kualitas. }\end{array}$ \\
\hline 4. & Pendukung & 1) & $\begin{array}{l}\text { Melakukan } \\
\text { pengembanga } \\
\text { n dan } \\
\text { pemeliharaan } \\
\text { jaringan untuk } \\
\text { menyokong, } \\
\text { mendukung } \\
\text { dan } \\
\text { mengarahkan } \\
\text { strategi TI. } \\
\text { Memiliki } \\
\text { dokumen } \\
\text { tentang } \\
\text { rencana } \\
\text { komunikasi } \\
\text { atau } \\
\text { pelaporan. }\end{array}$ & $\begin{array}{l}\text { 1)Tidak ada } \\
\text { dokumen terkait } \\
\text { sasaran dan } \\
\text { metrik untuk } \\
\text { pemantauan } \\
\text { yang disetujui. } \\
\text { 2) Tidak ada } \\
\text { dokumen } \\
\text { tentang matriks } \\
\text { keterampilan } \\
\text { dan kompetensi. }\end{array}$ \\
\hline
\end{tabular}

Tabel 6. Analisis kekuatan dan kelemahan (Lanjutan)

\begin{tabular}{|l|c|c|c|}
\hline No & Proses & Kekuatan & Kelemahan \\
\hline
\end{tabular}


Coding: Jurnal Komputer dan Aplikasi

Volume 8, No. 03 (2020), hal 29-39

\begin{tabular}{|c|c|c|c|}
\hline 4. & Pendukung & $\begin{array}{l}\text { 3) Memprioritask } \\
\text { an dan } \\
\text { mengalokasika } \\
\text { n sumber daya } \\
\text { untuk kegiatan } \\
\text { pemantauan. } \\
\text { 4) Mengklasifika } \\
\text { sikan sumber } \\
\text { informasi } \\
\text { berdasarkan } \\
\text { skema } \\
\text { klasifikasi } \\
\text { konten }\end{array}$ & $\begin{array}{l}\text { 3) Tidak ada } \\
\text { dokumen } \\
\text { tentang } \\
\text { pelaporan/kom } \\
\text { unikasi strategi } \\
\text { sumber daya }\end{array}$ \\
\hline 5. & Operasi & $\begin{array}{l}\text { 1) Melakukan } \\
\text { penilaian } \\
\text { terhadap } \\
\text { layanan TI saat } \\
\text { ini dan tingkat } \\
\text { layanan untuk } \\
\text { mengidentifika } \\
\text { si kesenjangan } \\
\text { antara layanan } \\
\text { yang ada dan } \\
\text { kegiatan bisnis } \\
\text { yang } \\
\text { didukungnya. } \\
\text { 2) Ada menyusun } \\
\text { perjanjian } \\
\text { layanan } \\
\text { dengan } \\
\text { pelanggan. } \\
\text { 3) Memiliki } \\
\text { dokumen } \\
\text { permintaan } \\
\text { perubahan } \\
\text { yang disetujui } \\
\text { dan yang } \\
\text { diterapkan. } \\
\text { 4) Memiliki } \\
\text { dokumen } \\
\text { kriteria } \\
\text { pendaftaran } \\
\text { masalah. }\end{array}$ & $\begin{array}{l}\text { 1) Tidak } \\
\text { mengevaluasi } \\
\text { kinerja dan } \\
\text { memberikan } \\
\text { pelaporan } \\
\text { kinerja } \\
\text { perjanjian } \\
\text { layanan reguler } \\
\text { dan formal, } \\
\text { termasuk } \\
\text { penyimpangan } \\
\text { dari yang } \\
\text { disepakati. } \\
\text { 2) Tidak ada } \\
\text { dokumen } \\
\text { tentang kinerja } \\
\text { tingkat layanan. } \\
\text { 3) Tidak ada } \\
\text { repositori } \\
\text { definisi } \\
\text { persyaratan. }\end{array}$ \\
\hline 6. & $\begin{array}{l}\text { Evaluasi } \\
\text { Kinerja }\end{array}$ & $\begin{array}{l}\text { 1) Melakukan } \\
\text { pemantauan } \\
\text { terhadap } \\
\text { alokasi dan } \\
\text { optimalisasi } \\
\text { sumber daya } \\
\text { sesuai dengan } \\
\text { tujuan dan } \\
\text { prioritas } \\
\text { menggunakan } \\
\text { sasaran dan } \\
\text { metrik yang } \\
\text { disepakati. } \\
\text { 2) Memiliki } \\
\text { dokumen } \\
\text { tentang umpan } \\
\text { balik alokasi } \\
\text { dan efektivitas } \\
\text { sumber daya } \\
\text { dan } \\
\text { kemampuan. }\end{array}$ & $\begin{array}{l}\text { 1) Tidak } \\
\text { melakukan } \\
\text { pemantauan } \\
\text { kualitas proses, } \\
\text { serta kualitas } \\
\text { nilai serta } \\
\text { memastikan } \\
\text { bahwa } \\
\text { pengukuran, } \\
\text { pemantauan } \\
\text { dan pencatatan } \\
\text { informasi } \\
\text { digunakan oleh } \\
\text { pemilik proses } \\
\text { untuk } \\
\text { mengambil } \\
\text { tindakan } \\
\text { korektif dan } \\
\text { pencegahan } \\
\text { yang tepat. }\end{array}$ \\
\hline
\end{tabular}

\begin{tabular}{|c|c|c|c|}
\hline & & $\begin{array}{l}\text { 3) Memiliki } \\
\text { dokumen } \\
\text { identifikasi } \\
\text { laporan } \\
\text { pemantauan } \\
\text { resolusi } \\
\text { masalah. } \\
\text { 4) Memiliki } \\
\text { dokumen } \\
\text { tentang hasil } \\
\text { analisis risiko. }\end{array}$ & $\begin{array}{l}\text { 2) Tidak ada } \\
\text { dokumen } \\
\text { tentang sasaran } \\
\text { dan metriks } \\
\text { sumber daya } \\
\text { yang disepakati. }\end{array}$ \\
\hline 7. & $\begin{array}{l}\text { Peningka- } \\
\text { tan }\end{array}$ & $\begin{array}{l}\text { 1) Memiliki } \\
\text { dokumen } \\
\text { solusi yang } \\
\text { diusulkan } \\
\text { untuk } \\
\text { kesalahan } \\
\text { yang } \\
\text { diketahui. } \\
\text { 2) Memiliki } \\
\text { dokumen } \\
\text { permintaan } \\
\text { layanan dan } \\
\text { insiden yang } \\
\text { ditutup. } \\
\text { 3) Memantau } \\
\text { dampak } \\
\text { berkelanjutan } \\
\text { dari masalah } \\
\text { dan kesalahan } \\
\text { yang terjadi } \\
\text { pada layanan. } \\
\text { 4) Memiliki } \\
\text { dokumen } \\
\text { tentang } \\
\text { masalah yang } \\
\text { telah ditutup. }\end{array}$ & $\begin{array}{l}\text { 1) Tidak } \\
\text { melakukan } \\
\text { identifikasi } \\
\text { masalah yang } \\
\text { mungkin } \\
\text { diketahui dari } \\
\text { membandingkan } \\
\text { data insiden } \\
\text { dengan database } \\
\text { kesalahan yang } \\
\text { diketahui dan } \\
\text { mengklasifikasi } \\
\text { kan masalah } \\
\text { tersebut sebagai } \\
\text { error yang } \\
\text { dikenal. } \\
\text { 2)Tidak ada } \\
\text { dokumen } \\
\text { tentang akar } \\
\text { penyebab } \\
\text { masalah. }\end{array}$ \\
\hline
\end{tabular}

\subsection{Rekomendasi Perbaikan}

Dari hasil analisis yang telah dilakukan sebelumnya didapat rekomendasi perbaikan untuk mencapai level yang diharapkan oleh KPP Pratama Pontianak Barat seperti pada tabel

5. Rekomendasi perbaikan yang dibuat, yaitu:

a. Rekomendasi perbaikan klausul 4 Konteks organisasi untuk mencapai level 4.

b. Rekomendasi perbaikan klausul 5 kepemimpinan untuk mencapai level 3.

c. Rekomendasi perbaikan klausul 6 perencanaan untuk mencapai level 3 .

d. Rekomendasi perbaikan klausul 7 pendukung untuk mencapai level 3.

e. Rekomendasi perbaikan klausul 8 operasi untuk mencapai level 2.

f. Rekomendasi perbaikan klausul 9 evaluasi kinerja untuk mencapai level 3.

g. Rekomendasi perbaikan klausul 10 peningkatan untuk mencapai level 3.

6. PENUTUP 
Coding: Jurnal Komputer dan Aplikasi

Volume 8, No. 03 (2020), hal 29-39

\subsection{Kesimpulan}

Berdasarkan pembahasan pada bab sebelumnya, dapat disimpulkan beberapa hal tentang sistem manajemen kualitas TI di KPP Pratama Pontianak Barat yaitu:

a. Proses manajemen kualitas TI pada penelitian ini berpedoman pada ISO 9001:2015 yang merupakan sebuah standar internasional untuk sistem manajemen kualitas yang berisi persyaratan atau klausul yakni konteks organisasi, kepemimpinan, perencanaan, pendukung, operasi, evaluasi kinerja dan peningkatan. Klausul tersebut diintegrasikan COBIT 5 untuk mendapatkan base practice dan work product untuk penilaian level 1. Untuk penilaian level 2 sampai level 5 menggunakan generic practice dan generic work product. Klausul ISO 9001:2015 dan COBIT 5 diintegrasikan berdasarkan kesamaan aspek yang saling melengkapi dan dapat dicocokkan.

b. Level kapabilitas pada klausul kepemimpinan, perencanaan, pendukung, operasi, evaluasi kinerja dan peningkatan berada pada level 1. Sedangkan untuk klausul konteks organisasi sudah berada pada level 2.

c. Secara keseluruhan KPP Pratama Pontianak Barat memiliki kesadaran tata kelola yang cukup baik, dapat dilihat dari level kapabilitas yang dicapai. Untuk klausul yang berada di level 1 artinya tujuan proses telah tercapai dan setiap prosesnya menghasilkan keluaran yang sesuai harapan. Dan untuk klausul yang berada di level 2 artinya proses yang telah dicapai pada level 1 diimplementasikan, dikelola dan hasilnya di tetapkan serta dikontrol.

\subsection{Saran}

Dari kesimpulan yang ada maka saran yang dapat diberikan untuk peningkatan kinerja KPP Pratama Pontianak Barat khususnya dalam tata kelola manajemen kualitas TI dan untuk penelitian serupa kedepannya yaitu:

a. Mendokumentasikan setiap proses yang dilakukan.

b. KPP Pratama Pontianak Barat mengimplementasikan rekomendasi perbaikan yang sesuai dengan level kerja KPP Pratama.

c. Rekomendasi perbaikan akan lebih baik bila dapat diimplementasikan langsung oleh pusat dalam hal ini Direktorat Teknologi
ISSN: 2338-493X

Informasi dan Komunikasi di Direktorat Jenderal Pajak.

d. Untuk penelitian serupa dikemudian hari, penelitian akan lebih efektif jika dilakukan pada instansi dan perusahaan tingkat pusat, karena dalam kuesioner ada menanyakan SOP, kebijakan atau aturan-aturan yang hanya diketahui atau dapat diakses oleh tingkat pusat.

\section{DAFTAR PUSTAKA}

[1] Al-rasyid, A (2015). Analisis Audit Sistem Informasi Berbasis COBIT 5 Pada Domain Deliver, Service, and Support ( DSS ) ( Studi Kasus : SIM-BL Di Unit CDC PT Telkom Pusat. Tbk ).

[2] Bernik, M., Sondari, M. C., dan Indika, D. R., (2017). Model of Quality Management System to Maintain Quality Consistency in Higher Education. Review of Integrative Business and Economics Research Online CDROM 6(4): 23041013.

[3] Van Grembergen, W., dan De Haes, S. (2009). Enterprise Governance of Information Technology: Achieving Strategic Alignment and Value Enterprise Governance of Information Technology: Achieving Strategic Alignment and Value.

[4] ITGI. (2003). Board Briefing on IT Governance 2nd Edition. IT Governance Institute.

[5] Wilson, J. P., dan Campbell, L. (2016). Developing a Knowledge Management Policy for ISO 9001: 2015. Journal of Knowledge Management 20(4): 829-44.

[6] Darsono. (2013). Analisis Pengendalian Kualitas Produksi Dalam Upaya Mengendalikan Tingkat Kerusakan Produk. Jurnal Ekonomi - Manajemen Akuntansi 20(35): 1-17.

[7] ISACA. (2012). COBIT 5 Enabling Processes. Rolling Meadows, IL 60008 USA,United States of America: ISACA. 
Coding: Jurnal Komputer dan Aplikasi

Volume 8, No. 03 (2020), hal 29-39

[8] ISACA. (2012). COBIT Process

Assessment Model (PAM). Rolling Meadows, USA: ISACA.

[9] Mutiah, N. (2019). Penilaian Tata Kelola Teknologi Informasi Universitas Tanjungpura Menggunakan Cobit 5 Domain Align, Plan, Dan Organise (APO). Computer Engineering, Science and System Journal 4(1): 65.

[10] Yildirim, T., dan Metin, B. (2013). Convenient Quality Control for IT Governance-Aware Enterprises. ISACA JOURNAL 1: 1-4. 